\title{
Antithrombotic Effect of Mucuna pruriens L. and Coriandrum sativum
}

\author{
Nuriza Ulul Azmi, Astari Rachma Nityasa, Fadlina Chany Saputri
}

\section{Nuriza Ulul Azmi, Astari Rachma Nityasa, Fadlina Chany Saputri}

Department of Pharmacology, Faculty of Pharmacy, Universitas Indonesia, Depok, INDONESIA.

\section{Correspondence}

Dr. Fadlina Chany Saputri

Department of Pharmacology, Faculty of Pharmacy, Universitas Indonesia, Kampus UI, Depok 16424, INDONESIA.

Phone no: +62-21-7270031

E-mail: fadlina.chany@farmasi.ui.ac.id

\section{History}

- Submission Date: 04-07-2018;

- Review completed: 02-08-2018;

- Accepted Date: 22-11-2018

\section{DOI : 10.5530/pj.2019.11.64}

Article Available online

http://www.phcogj.com/v11/i1

\section{Copyright}

(C) 2019 Phcog.Net. This is an openaccess article distributed under the terms of the Creative Commons Attribution 4.0 International license.

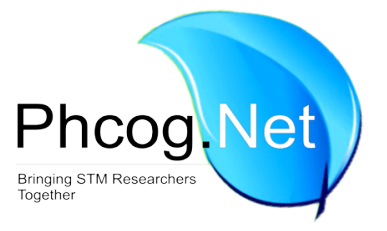

\begin{abstract}
Background: Mucuna pruriens (MP) L. and Coriandrum sativum (CS) have been found for in vitro antithrombotic activity. However, the in vivo studies for both plants have not been discovered yet. Objective: The objective of the study is to prove the efficacy of MP L. and CS by conducting in vivo antithrombotic activity test with bleeding time and survival rate as the parameters. Materials and Methods: MP and CS extracts with three different doses were given orally to the experimental animals for 7 days. Aspirin was used as a positive control. The bleeding time was observed on mice tail that had been cut, and the survival rate was determined by inducing thrombosis with collagen-epinephrine injection. Results: Seven-day treatment of plant extracts significantly prolonged the bleeding time of the treated group compared to the normal control group. The result demonstrated the increasing number of survived animals in the treated group compared to the negative control group. Conclusion: Both extracts had shown antithrombotic activity by significantly prolonged the bleeding time and increased the survival rate.

Keywords: Antithrombotic, bleeding time, collagen, Coriandrum sativum, Mucuna pruriens L,
\end{abstract} survival rate

\section{INTRODUCTION}

Thrombosis is a serious pathological issue that causes high rates of morbidity and mortality. ${ }^{1}$ Thrombus formed in the circulatory system due to loss of homeostasis can cause vascular blockage, atherothrombotic diseases, myocardial or cerebral necrosis that will lead to death. ${ }^{2}$ Despite being essential to maintaining the vascular integrity and bleeding through blood clot formation, platelets are also implicated in the pathological progression of arterial vascular thrombosis. The pathological mechanisms are through their adherence to the sites of injured vessel tissue, an aggregation to a plug forming, and accelerating coagulation cascades. ${ }^{3,4}$ Inhibiting the platelet aggregation is one of the mechanisms to prevent cardiovascular disease that reported as number one cause of death. ${ }^{1}$ Aspirin has been widely used as an antiplatelet agent and in the prevention of atherosclerotic event. ${ }^{5}$ However, the previous study reported that some patients have resistance to aspirin, resulting in poor therapy result. ${ }^{6}$ Thus, some studies have been conducted to discover antithrombotic agents from a medicinal plant.

Mucuna pruriens (MP) L. and Coriandrum sativum (CS) are widely used in Indonesia as food, spice, and kitchen herb. Besides that, both plants had been found for some medicinal properties including in antithrombotic activity. Previous studies showed that MP L. extract could prevent thrombosis with its antithrombotic activity in hypercholesterolemic rat $^{7}$ and inhibit the adenosine diphosphate-induced human platelet aggregation. ${ }^{8}$ Another study reported that the total polyphenolic content of MP methanol extract has high antioxidant activity. ${ }^{9}$ Furthermore, the herb part of CS contains rutin which had been found to possess antiplatelet activity by inhibiting ion $\mathrm{Ca}^{2+}$ mobilization and thromboxane A2 (TXA2) formation. ${ }^{10,11}$

Supported by literature data, this study aimed to further investigate the antiplatelet and antithrombotic activities of MP L. and CS. Antithrombotic activity in this study was examined by measuring the bleeding time and survival rate. ${ }^{12}$

\section{MATERIALS AND METHODS}

\section{Chemicals and plant materials}

Epinephrine was obtained from Sigma-Aldrich (Nucleos, Singapore) and carboxymethylcellulose (CMC) was from Brataco (Jakarta, Indonesia). Aspirin, collagen, and other chemical reagents were purchased from Sigma-Aldrich (Tokyo, Japan).

Extract of MP and plant material of CS were obtained from Indonesian Spice and Medicinal Crops Research Institute, Bogor, and the voucher specimens were deposited at Center for Plant Conservation Botanic Gardens (No. B-1691/IPH.3/KS/ $\mathrm{VI} / 2017)$. The dried and powdered leaves of CS were decocted for $30 \mathrm{~min}$ in $90^{\circ} \mathrm{C}$. The extracts were dissolved in sodium CMC (CMC-Na) suspension. 


\section{Phytochemical screening}

Phytochemical screening was done to identify the presence of metabolite and biologically active compounds in the plant extracts. The screening for identification of alkaloids, saponins, tannins, flavonoids, terpenoids, and glycosides was performed using standard procedures. ${ }^{13,14}$

\section{Total flavonoid and phenolic contents}

Total flavonoid content was determined by making a working solution at first. Plant extract equivalent to $200 \mathrm{mg}$ of aqueous extract was added $1 \mathrm{~mL}$ of $0.5 \%$ hexamethylenetetramine, $20 \mathrm{~mL}$ of acetone, and $2 \mathrm{~mL}$ of $25 \% \mathrm{HCl}$. The suspension was then refluxed for $30 \mathrm{~min}$ and filtered. After that, $20 \mathrm{~mL}$ of filtrate was extracted with ethyl acetate three times, and the ethyl acetate fraction was collected as a working solution. Blank solution was made by adding glacial acetic acid into $10 \mathrm{~mL}$ of working solution. The sample solution was prepared by adding $1 \mathrm{~mL}$ of $2 \%$ aluminum trichloride and glacial acetic acid to $10 \mathrm{~mL}$ of working solution. The total phenolic content was determined by Folin-Ciocalteu test and was measured in $\lambda=725 \mathrm{~nm}$.

\section{Experimental animals}

This study used male DDY strain mice (Mus musculus) weighing 20-30 g from Faculty of Veterinary, Bogor Agriculture Institute. All mice were allowed free access to food and water and housed in $12 \mathrm{~h}$ light-dark periods. The acclimatization was done for 2 weeks before the experiments. This study was approved by The Ethics Committee of Faculty of Medicine, Universitas Indonesia (No. 232/UN2.F1/ETIK/2017).

\section{Animal treatment}

This study was conducted by in vivo experimental with parameters of bleeding time and survival rate. Bleeding time was determined by tail bleeding assay which uses a total of 25 DDY mouse for each plant extract that was divided randomly into five groups of five animals as follow:

1. Group I: Normal control group, treated with $0.5 \%$ CMC-Na suspension for $7 \mathrm{~d}$

2. Group II: Positive control group, treated with aspirin $(0.208 \mathrm{mg} / 20 \mathrm{~g}$ body weight $\mathrm{BW} /$ mice/day) for $7 \mathrm{~d}$

3. Group III: D1 group, treated with the plant extract (MP extract: $7 \mathrm{mg} / 20 \mathrm{~g}$ BW/mice/day; CS extract: $1.5 \mathrm{mg} / 20 \mathrm{~g} \mathrm{BW} / \mathrm{mice} /$ day) for $7 \mathrm{~d}$

4. Group IV: D2 group, treated with the plant extract (MP extract: $14 \mathrm{mg} / 20 \mathrm{~g}$ BW/mice/day; CS extract: $3 \mathrm{mg} / 20 \mathrm{~g} \mathrm{BW} /$ mice/day) for $7 \mathrm{~d}$

5. Group V: D3 group, treated with the plant extract (MP extract: $28 \mathrm{mg} / 20 \mathrm{~g}$ BW/mice/day; CS extract: $6 \mathrm{mg} / 20 \mathrm{~g}$ BW/mice/day) for $7 \mathrm{~d}$.

Survival rate test was done by dividing randomly into six groups of five animals: normal control, positive control, negative control, and three sample groups in different doses for each plant extract. Animals were treated both in bleeding time and survival tests orally $(0.3 \mathrm{~mL} / 20 \mathrm{~g} \mathrm{BW} /$ mice/day) with the corresponding agents for $7 \mathrm{~d}$.

\section{Tail bleeding assay}

On the last day of treatment, after $5 \mathrm{~h}$ of administration, animals were anesthetized. The tail was cut $10 \mathrm{~mm}$ from the tip by and immediately immersed into isotonic saline solution inside a tube. Each mouse was observed for $20 \mathrm{~min}$ to determine the bleeding time. The experiment will be stopped after $20 \mathrm{~min}$ to prevent the death of experimental animals. ${ }^{15}$

\section{Pulmonary thromboembolism model}

Survival rate was determined by using pulmonary thromboembolism model in experimental mice as described by Saputri et al., with a slight modification. ${ }^{16}$ After $24 \mathrm{~h}$ of the last administration, experimental animals (positive, negative, D1, D2, and D3 groups) were injected with collagen-epinephrine (700 $\mu \mathrm{g}: 42 \mu \mathrm{g}$ ) solution to induce thrombosis while the normal control group was given an injection of isotonic saline solution. The observation was done for $15 \mathrm{~min}$ to determine the total lethal or paralyzed effects. Efficacy percentage of the three extracts was obtained by comparing to the normal control group, and the survival rate $(\%)$ was calculated with the formulation:

$$
1-\left(\frac{\text { amount of dead animals }}{\text { amount of animals in the group }}\right) \times 100 \%
$$

\section{Statistical analysis}

The obtained data were processed statistically. Homogeneity of data was determined with Levene test, and the normality of data was analyzed with the Shapiro-Wilk test. One-way ANOVA test was performed and the relation between each treatment group was observed by the least significant difference test. $P<0.05$ was considered to be statistically significant.

\section{RESULTS}

\section{Phytochemical screening}

The phytochemical screening results of MP and CS extract were summarized in Table 1. It showed the presence of alkaloid, saponin, flavonoid, and glycoside in MP extract, while tannin and terpenoid were tested negative. On the other hand, CS extract was found to contain only saponin and glycoside.

\section{Total flavonoid and phenolic contents}

Total flavonoid and phenolic content of MP extract was found at $0.002 \%$ and $0.650 \%$, respectively. On the other hand, the total flavonoid and phenolic content of CS extract were $0.439 \%$ and $0.260 \%$, respectively.

\section{Bleeding time}

Compared to the normal control group, 7 days of treatment with MP and CS extract increased the bleeding time in mice. As shown in Table 2, the bleeding time of positive control group and treated groups were significantly different from the normal control group $(P<0.05)$. This study demonstrated that the highest mean value of bleeding time was shown by MP D2 group (17.61 \pm 3.02$)$. Figure 1 shows that all doses of

\section{Table 1: Phytochemical screening of Mucuna pruriens and Coriandrum} sativum leaves extract

\begin{tabular}{ccccc}
\hline $\boldsymbol{n}$ & Metabolite & Test reagent & MP & CS \\
\hline 1 & Alkaloids & Bouchardat & + & - \\
& & Dragendorff & + & - \\
& & Mayer & - & - \\
2 & Tannins & NaCl-gelatin & - & + \\
3 & Saponins & $\mathrm{HCl} 2 \mathrm{~N}$ & + & - \\
4 & Flavonoids & $\mathrm{Mg}+\mathrm{HCl}$ & + & - \\
5 & Terpenoids & Lieberman bouchard & - & + \\
6 & Glycosides & Molisch & + & + \\
\hline
\end{tabular}

MP: Mucuna pruriens extract; CS: Coriandrum sativum leaves extract 
Table 2: Mean value of bleeding time

\begin{tabular}{ccc}
\hline \multirow{2}{*}{ Groups } & \multicolumn{2}{c}{ Bleeding time $($ mean \pm SD) } \\
\cline { 2 - 3 } & MP & CS \\
\hline Normal & $7.18 \pm 1.26$ & $7.33 \pm 1.19$ \\
Positive & $15.89 \pm 2.33^{*}$ & $15.63 \pm 4.13^{*}$ \\
D1 & $17.04 \pm 2.18^{*}$ & $17.18 \pm 1.86^{*}$ \\
D2 & $17.61 \pm 3.02^{*}$ & $15.54 \pm 3.57^{*}$ \\
D3 & $16.97 \pm 1.92^{*}$ & $17.44 \pm 1.82^{*}$ \\
\hline
\end{tabular}

Normal (CMC 0.5\% volume: $0.3 \mathrm{~mL} / 20 \mathrm{~g} \mathrm{BW}$ ), positive (aspirin $0.208 \mathrm{mg} / 20 \mathrm{~g}$ BW), MP D1 (MP extract $7 \mathrm{mg} / 20 \mathrm{~g} \mathrm{BW}$ ), MP D2 (MP extract $14 \mathrm{mg} / 20 \mathrm{~g} \mathrm{BW}$ ), MP D3 (MP extract $28 \mathrm{mg} / 20 \mathrm{~g} \mathrm{BW})$, CS D1 (1.5 mg/20 g BW), CS D2 (3 mg/20 g $\mathrm{BW}), \mathrm{CS} \mathrm{D} 3(6 \mathrm{mg} / 20 \mathrm{~g} \mathrm{BW}) .{ }^{*} P<0.05$ as compared to the normal group. MP: Mucuna pruriens extract; CS: Coriandrum sativum leaves extract; BW: Body weight; SD: Standard deviation; CMC: Carboxymethylcellulose

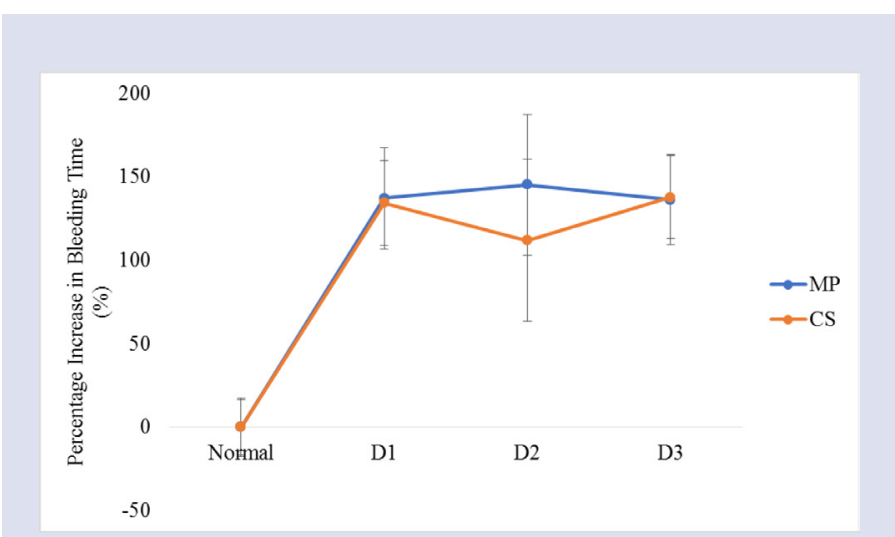

Figure 1: The percentage increase in bleeding time of Mucuna pruriens extract and Coriandrum sativum extract. MP: Mucuna pruriens extract; CS: Coriandrum sativum leaves extract

$\mathrm{MP}$ and CS extract prolonging the bleeding time as compared to the normal control group. Even with the lowest dose of extract could prolong the bleeding time more than $100 \%$ increase or two-fold compared to the normal control group.

\section{Survival rate}

Compared to the negative control group, 7 days of treatment with MP and CS extracts increased the survival rate in treated groups. As shown in Table 3, the highest survival rate was demonstrated by CS D1 (80\%) with the dose given of $1.5 \mathrm{mg} / 20 \mathrm{~g}$ body weight (BW).

\section{DISCUSSION}

Beside the function of platelets in the human primary hemostatic mechanism that essential in the control of bleeding through forming blood clot, they are also contributed to the atherosclerosis progression and arterial vascular thrombosis. ${ }^{17-20}$ It is important to evaluate the function of platelet to developing the antithrombotic agent and preventing the prevalence of cardiovascular disease. This study was conducted to find the in vivo effect of MP L. and CS as the antithrombotic agent.

This in vivo study showed the antithrombotic effect of MP L. and CS administered orally in mouse thrombotic model by conducting bleeding time and survival rate tests.

\begin{tabular}{ccc} 
Table 3: The result of survival rate \\
\hline Groups & \multicolumn{3}{c}{ Survival rate (\%) } \\
\cline { 2 - 3 } & MP & CS \\
\hline Normal & - & - \\
Positive & 100 & 100 \\
Negative & 0 & 0 \\
D1 & 40 & 80 \\
D2 & 60 & 40 \\
D3 & 40 & 40 \\
\hline
\end{tabular}

Normal (CMC $0.5 \%$ volume: $0.3 \mathrm{~mL} / 20 \mathrm{~g} \mathrm{BW}$ ), positive (aspirin $0.208 \mathrm{mg} / 20 \mathrm{~g}$ BW), MP D1 (MP extract $7 \mathrm{mg} / 20 \mathrm{~g} \mathrm{BW}$ ), MP D2 (MP extract $14 \mathrm{mg} / 20 \mathrm{~g} \mathrm{BW}$ ), MP D3 (MP extract $28 \mathrm{mg} / 20 \mathrm{~g} \mathrm{BW}$ ), CS D1 (1.5 mg/20 g BW), CS D2 (3 mg/20 g BW), CS D3 (6 mg/20 g BW). MP: Mucuna pruriens extract; CS: Coriandrum sativum leaves extract; BW: Body weight; CMC: Carboxymethylcellulose

MP L. extract exerts the increase of bleeding time longer than positive group (aspirin) compared to normal group. Genistein contained in MP inhibited platelet activation and aggregation by receptor TXA2 mechanism. ${ }^{7,21}$ By inhibiting TXA2 receptors, protein kinase $\mathrm{C}$ activation will be inhibited, and ion $\mathrm{Ca}^{2+}$ decreased which further inhibit platelet activation. Inhibition of platelet activation and aggregation can prevent the formation of thrombus. Thus, make the blood flow run smoothly. In MP group, D1 and D2 are in a dose-dependent manner, but the bleeding time is decreasing in D3 group even though it is still significantly different with the normal group. It may be due to D3 was not included in the optimum dose range of MP as an antithrombotic agent. Aqueous MP extract reported having optimum dose $500 \mathrm{mg} / 200 \mathrm{~g}$ in the previous study with hypercholesterolemia rats.?

CS extract significantly increased bleeding time in mice compared to the normal group. It was reported that CS contains polyphenols constituent that inhibits platelet activation and aggregation through inhibition of ion $\mathrm{Ca}^{2+}$ mobilization. ${ }^{10,22}$ The inhibition of ion $\mathrm{Ca}^{2+}$ mobilization further inhibits platelet activation resulting in thinner blood consistency. Rutin contained in CS extract possess inhibitor activity on platelet aggregation by inhibiting platelet phospholipase C. ${ }^{21,23}$

For survival rate test, the collagen-epinephrine combination was used in this study as thrombosis inducer. Collagen has a major role as platelet activator after damage to vessel tissue. Collagen induces TXA and inositol production which later induces $\mathrm{Ca}^{2+}$ mobilization. Then, $\mathrm{Ca}^{2+}$ mobilization activates platelet that signed with shape change, granule secretion, and aggregation. ${ }^{24}$ The highest number of survival rate was shown by CS D1 (80\%). In MP group, D1 and D2 are in a dose-dependent manner, but the survival rate is decreasing in D3 group even though it is still significantly different with the normal group. It may be due to D3 was not included in the optimum dose range of MP as an antithrombotic agent. The previous study about genistein as antiplatelet showed that the effectivity of genistein against collagen depends on the collagen concentration. The effect from genistein with a concentration of 30 and $100 \mu \mathrm{M}$ can inhibit collagen-induced thrombosis with collagen concentration $1 \mu \mathrm{g} / \mathrm{ml} .^{25}$ Even if there is inhibitory activity in lower or higher dose, the result is not as good as in optimum dose.

In CS-treated group showed the increasing of bleeding time in three given dose, but there is a decrease in D2 and D3 group which survival rate is $40 \%$. The decrease of survival rate may be due to D2 and D3 was not included in an optimum dose range of CS as platelet activation inhibitor that induced by collagen. In previous in vitro study has reported that CS leaves have an optimum dose at $1.1 \mathrm{mg} / \mathrm{mL}$ to inhibit $0.005 \%$ collagen. ${ }^{22}$ 
As shown in phytochemical screening result for both extracts, the presence of saponin may be responsible for antithrombotic activity in male mice. Saponin has been reported to inhibit collagen-induced platelet activation by inhibiting calcium mobilization. ${ }^{26}$ Moreover, in the previous study, saponin has shown antithrombotic activity by inhibiting platelet aggregation. ${ }^{27,28}$ Other compounds contained in MP extract may also carry influence to that activity such as flavonoid or polyphenol.

\section{CONCLUSION}

MP L. and CS had shown antithrombotic activity in male mice by significantly increasing the bleeding time and survival rate. These results confirm previous in vitro studies. Further studies are recommended to determine the specific constituent and mechanism of action.

\section{Abbreviations used}

CMC: Carboxymethylcellulose; CS: Coriandrum sativum; HMT: Hexamethylenetetramine; LSD test: Least Significant Difference Test; MP: Mucuna pruriens; TXA2: Thromboxane A2.

\section{Acknowledgment}

This study is supported by Faculty of Pharmacy, Universitas Indonesia and funded by Hibah PITTA 2017 Universitas Indonesia.

\section{Financial support and sponsorship}

This study is supported by Faculty of Pharmacy, Universitas Indonesia and funded by Directorate of Research and Community Engagement (PITTA Grant 2017), Universitas Indonesia.

\section{Conflicts of interest}

There are no conflicts of interest.

\section{REFERENCES}

1. Smith SC Jr., Collins A, Ferrari R, Holmes DR Jr., Logstrup S, McGhie DV, et al. Our time: A call to save preventable death from cardiovascular disease (heart disease and stroke). J Am Coll Cardiol 2012;60:2343-8.

2. Kabir MS, Hossain MM, Kabir MI, Rahman MM, Hasanat A, Emran TB, et al. $\alpha$-amylase inhibition and cytotoxic activities of ethanol extract of Steudnera colocasiifolia K. Koch leaves. J Young Pharm 2016;8:391-7.

3. Guyton AC, Hall JE. Textbook of Medical Physiology. $10^{\text {th }}$ ed. Philadelphia: W.B. Saunders; 2000

4. Silverthorn DU, Johnson BR. Human Physiology. $5^{\text {th }}$ ed. San Fransisco: Pearson/ Benjamin Cummings; 2010.

5. Clappers N, Brouwer MA, Verheugt FW. Antiplatelet treatment for coronary heart disease. Heart 2007;93:258-65.

6. Poulsen TS, Kristensen SR, Korsholm L, HaghfeltT, Jørgensen B, Licht PB, et al. Variation and importance of aspirin resistance in patients with known cardiovascular disease. Thromb Res 2007;120:477-84

7. Widowati W, Ratnawati H, Rusidi UD, Winarno W, Immanuel V. Phytochemical assay and antiplatelet activity of fractions of velvet bean seeds (Mucuna pruriens L.). Hayati J Biosci 2010;17:85-90

8. Herrera Chalé F, Ruiz Ruiz JC, Betancur Ancona D, Acevedo Fernández JJ, Segura Campos MR. The hypolipidemic effect and antithrombotic activity of Mucuna pruriens protein hydrolysates. Food Funct 2016;7:434-44.

9. Freedman JE, Parker C 3rd, Li L, Perlman JA, Frei B, Ivanov V, et al. Select flavonoids and whole juice from purple grapes inhibit platelet function and enhance nitric oxide release. Circulation 2001;103:2792-8.

10. Sheu JR, Hsiao G, Chou PH, Shen MY, Chou DS. Mechanisms involved in the antiplatelet activity of rutin, a glycoside of the flavonol quercetin, in human platelets. J Agric Food Chem 2004;52:4414-8.

11. Laribi B, Kouki K, M'Hamdi M, Bettaieb T. Coriander (Coriandrum sativum L.) and its bioactive constituents. Fitoterapia 2015;103:9-26.

12. Ryu KH, Han HY, Lee SY, Jeon SD, Im GJ, Lee BY, et al. Ginkgo biloba extract enhances antiplatelet and antithrombotic effects of cilostazol without prolongation of bleeding time. Thromb Res 2009;124:328-34.

13. Departemen Kesehatan Republik Indonesia. Medical Material of Indonesia $4^{\text {th }}$ ed. Jakarta: Departemen Kesehatan Republik Indonesia; 1995.

14. Nandagoapalan V, Doss A, Marimuthu C. Phytochemical analysis of some traditional medicinal plants. Biosci Discov 2015;7:17-20.

15. LiuY, Jennings NL, Dart AM, Du XJ. Standardizing a simpler, more sensitive and accurate tail bleeding assay in mice. World J Exp Med 2012;2:30-6.

16. Saputri FC, Nabila N, Mun'im A. Combination of ginger and sappan wood extract effect on in vivo antithrombotic activity test observation result of bleeding time. J Young Pharm 2017;9:46-8.

17. Jin YR, Hwang KA, Cho MR, Kim SY, Kim JH, Ryu CK, et al. Antiplatelet and antithrombotic activities of CP201, a newly synthesized 1,4-naphthoquinone derivative. Vascul Pharmacol 2004:41:35-41.

18. Ruggeri ZM. Platelets in atherothrombosis. Nat Med 2002;8:1227-34.

19. Tang Z, Wang Y, Xiao Y, Zhao M, Peng S. Anti-thrombotic activity of PDR, a newly synthesized L-arg derivative, on three thrombosis models in rats. Thromb Res 2003; 110:127-33.

20. Michelson AD, Frelinger AL $3^{\text {rd }}$, Furman MI. Current options in platelet function testing. Am J Cardiol 2006;98:4N-10N.

21. Fuentes E, Palomo I. Antiplatelet effects of natural bioactive compounds by multiple targets: food and drug interactions. J Funct Food 2014;6:73-81.

22. Suneetha J, Krishnakantha T. Antiplatelet activity of coriander and curry leaf spices. Pharm Biol 2005;43:230-3.

23. Oganesyan ET, Nersesyan ZM, Parkhomenko AY. Chemical composition of the above-ground part of Coriandrum sativum. Pharm Chem J 2007;41:149-53.

24. Roberts DE, McNicol A, Bose R. Mechanism of collagen activation in human platelets. J Biol Chem 2004;279:19421-30

25. Kondo K, Suzuki Y, Ikeda Y, Umemura K. Genistein, an isoflavone included in soy, inhibits thrombotic vessel occlusion in the mouse femoral artery and in vitro platelet aggregation. Eur J Pharmacol 2002;455:53-7.

26. Jeon BR, Kim SJ, Hong SB, Park HJ, Cho JY, Rhee MH, et al. The inhibitory mechanism of crude saponin fraction from Korean red ginseng in collageninduced platelet aggregation. J Ginseng Res 2015;39:279-85.

27. Qi H, Huang $Y$, Yang $Y$, Dou G, Wan F, Zhang W, et al. Anti-platelet activity of panaxatriol saponins is mediated by suppression of intracellular calcium mobilization and ERK2/p38 activation. BMC Complement Altern Med 2016;16:174

28. Shin JH, Kwon HW, Cho HJ, Rhee MH, Park HJ. Inhibitory effects of total saponin from korean red ginseng on $\mathrm{Ca}(2+)$ i mobilization through phosphorylation of cyclic adenosine monophosphate-dependent protein kinase catalytic subunit and inositol 1,4,5-trisphosphate receptor type I in human platelets. J Ginseng Res 2015:39:354-64.

Cite this article: Azmi NU, Nityasa AR, Saputri FC. Antithrombotic effect of Mucuna pruriens L. and Coriandrum sativum. Pharmacog J. 2019;11(2):413-7. 
GRAPHICAL ABSTRACT

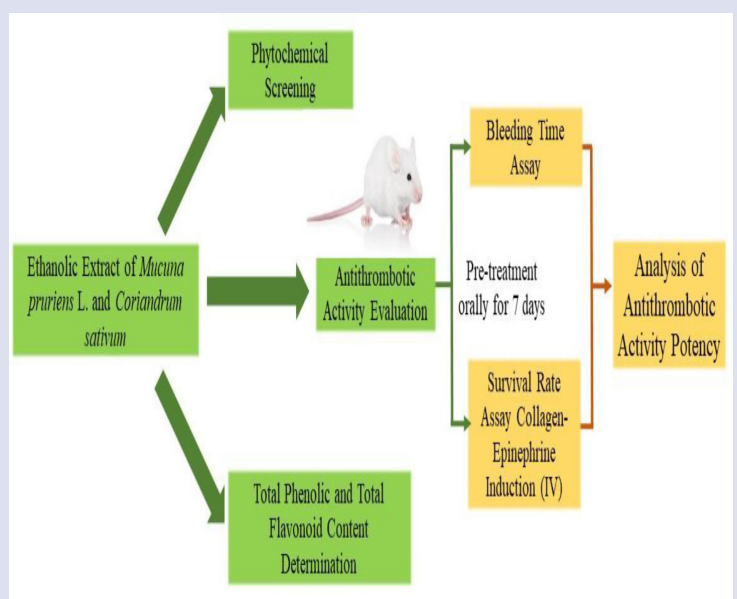

\section{SUMMARY}

1. All groups of mouse given orally of Mucuna pruriens and Coriandrum sativum extracts with three different doses for 7 days significantly prolonged the bleeding time compared to the normal group $(P<0.05)$ with more than $100 \%$ increase

2. Mucuna pruriens D2 group with dose given $14 \mathrm{mg} / 20 \mathrm{~g}$ body weight showed the highest mean value of bleeding time $(17.61 \pm 3.02)$

3. Mouse groups with a 7-day treatment of Mucuna pruriens and Coriandrum sativum extract increased the survival rate compared to the negative control

4. The highest survival rate was shown by Coriandrum sativum D1 (1.5 mg/20 g body weight) with $80 \%$ increase in the number of surviving animals

5. Antithrombotic activity of Mucuna pruriens and Coriandrum sativum had been shown in male mice by significantly increasing the bleeding time and survival rate

6. Phytochemical screening result for both extracts showed the presence of saponin that may be responsible for antithrombotic activity in male mice 